\title{
Mendongeng Digital sebagai Media Peningkatan Soft Skill Santri Sanggar Baca Jendela Dunia
}

\author{
Latifah $^{1}$, Indrani Dewi Anggraini ${ }^{2}$, Wiwit Sariasih ${ }^{3}$, Mia Perlina $^{4}$ \\ Universitas Pamulang ${ }^{1234}$ \\ Korespondensi: dosen00608@unpam.ac.id ${ }^{1}$,dosen00113@unpam.ac.id ${ }^{2}$, \\ dosen01268@unpam.ac.id ${ }^{3}$,dosen00322@unpam.ac.id ${ }^{4}$
}

\begin{abstract}
Sanggar Baca Jendela Dunia (SBJD) which is located at RT 01 RW 02 Legoso Ciputat Timur was founded due to the concern about the low reading interest of the children in the neighbourhood. Therefore, SBJD seeks to improve the literacy skills of the children. Thus, this Community Service (PkM) aims to improve soft skills as well as encourage and improve digital literacy skills through a variety of educational and fun activities to attract the SBJD students' interest. The method used in this PkM activity was carried out through digital story telling developed through discussion, games, and singing. In addition, the assessment was carried out using Whiteboard.fi which guides the students to acquire knowledge and skills related to digital literacy. The PkM activity was attended by 30 students with an age range of 4-12 years. From the results, the students took part in a series of activities enthusiastically and joyfully. The literacy skills of the students were shown by the use of Zoom as a medium for carrying out activities, Power Point for presenting the materials, and the Whiteboard.fi which allows students to experiment. Besides, storytelling that was delivered has built the participants soft skills such as self-confidence, grateful, and respectful.
\end{abstract}

Keywords: digital literacy, sanggar baca, soft skills, story telling

\begin{abstract}
Abstrak
Sanggar Baca Jendela Dunia (SBJD) yang berlokasi di RT 01 RW 02 Legoso Ciputat Timur didirikan atas dasar keprihatinan terhadap rendahnya minat baca anak-anak di lingkungan setempat. Atas pertimbangan hal tersebut, SBJD pun kemudian berupaya untuk meningkatkan kemampuan literasi anak-anak. Oleh karena itu, kegiatan PkM ini bertujuan untuk meningkatkan soft skill sekaligus mendorong dan meningkatkan kemampuan literasi digital melalui variasi kegiatan yang edukatif dan menyenangkan untuk menarik minat para peserta didik/santri SBJD. Metode yang digunakan dalam kegiatan PkM ini dilaksanakan melalui kegiatan mendongeng digital yang dikembangkan melalui diskusi, bermain, dan bernyanyi. Selain itu, asesmen dilakukan dengan memanfaatkan aplikasi whiteboard.fi yang menuntun para santri memperoleh pengetahuan dan keterampilan terkait digital literasi. Kegiatan PkM diikuti oleh 30 santri dengan rentang usia 4-12 tahun. Dari hasil kegiatan PkM, para santri mengikuti rangkaian kegiatan dengan antusias tinggi dan ceria. Kemampuan literasi para santri ditunjukkan dengan penggunaan Zoom sebagai media pelaksanaan kegiatan, Power Point sebagai media presentasi dongeng dan materi penguatan dan pengembangan tentang dongeng, serta asesmen dengan aplikasi Whiteboard. $f i$ yang memungkinkan para santri untuk bereksperimen. Selain itu, melalui dongeng yang disampaikan, para peserta juga mendapat pendidikan karakter sehingga terbentuknya rasa percaya diri, menjadi pribadi yang bersyukur, dan saling menghormati.
\end{abstract}

Kata kunci: literasi digital, mendongeng, pendidikan karakter, sanggar baca 


\section{A. Pendahuluan}

Pendidikan anak usia sekolah dasar memerlukan perhatian yang cukup besar baik dari segi isi pembelajaran, metode maupun fasilitas belajar. Hal ini sangat penting untuk menunjang tumbuh kembang anak, tidak hanya dari segi kognitif namun juga dari segi afektif dan psikomotornya. Pendidikan pada usia sekolah dasar ini menjadi perhatian yang cukup besar terutama pada masa pandemi Covid-19 saat ini dimana pemerintah memberlakukan sistem pembelajaran jarak jauh. Pemberlakuan pembelajaran jarak jauh ini mewajibkan anak-anak untuk melakukan kegiatan belajar melalui jarak jauh sambil melakukan isolasi mandiri di rumah tentunya dengan didampingi oleh orang tua. Berdasarkan pertimbangan tersebut perlu dikembangkan kegiatan yang menyenangkan untuk anak, beragam pilihan kegiatan dapat dilakukan sesuai dengan prinsip belajar anak yaitu belajar melalui bermain sambil belajar dan tentunya juga diiringi dengan pendidikan soft skill atau pendidikan karakter yang akan membentuk anak menjadi pribadi yang tangguh, mampu bersosialisasi dengan baik, memiliki daya juang dalam belajar dan memiliki sifat saling menghormati, mandiri dan berwawasan luas.

Pembelajaran di rumah yang inovatif dengan sistem bermain namun juga tetap mempertimbangkan segi kognitif, afektif dan psikomotor siswa sekolah dasar juga menjadi satu hal yang menjadi perhatian bagi Sanggar Baca Jendela Dunia. Sanggar Baca Jendela Dunia dirintis sejak 29 Juli 2007 oleh Ibu Karlina Helmanita, MA dan secara resmi didirikan atas dukungan suami tercinta, bapak Dr. Sihabudin Noor, MA. Keduanya dosen UIN Syarif Hidayatullah Jakarta. Pendirian ini ditandai dengan peringatan satu tahun Sanggar Baca Jendela Dunia dalam launching pustaka komunitas dan khatam al-Qur'an pada10 Agustus 2008 oleh Direktur Jenderal Perguruan Tinggi Kementrian Pendidikan Nasional, Prof. Dr. Fasli Jalal yang dilegalkan dengan akta notaris Lilik Martono, SH pada 1 Oktober 2010. Latar belakang pendirian Sanggar Baca Jendela Dunia berangkat dari keprihatinan keduanya pada rendahnya minat baca di lingkungan tempat tinggal mereka di RT 01 RW 02 Legoso Ciputat Timur, dan minimnya sumber daya manusia pada rasa cinta pada baca tulis baik al-Qur'an dan baca non qur'ani secara sistematis dan profesional. Sanggar baca Jendela Dunia juga berupaya untuk meningkatkan kemampuan literasi anak-anak sekolah dasar usia 6-12 tahun. Hal ini kemudian menjadi dasar untuk menjalin kerjasama antara dosen dan mahasiswa Universitas Pamulang dengan pihak sanggar yang diwujudkan dalam bentuk kegiatan pengabdian kepada masyarakat.

Untuk meningkatkan kemampuan literasi sekaligus menerapkan pembelajaran daring yang menarik dan inovatif, maka kegiatan pengabdian kepada masyarakat di Sanggar Baca Jendela Dunia dilaksanakan dalam bentuk mendongeng digital sebagai media peningkatan soft skill peserta didik atau santri. Kegiatan mendongeng ini diadakan dalam bentuk dongeng digital pada para santri yang berusia antara 4-12 tahun secara daring dengan nuansa bermain sambil belajar dan membentuk karakter peserta didik/santri. Mendongeng digital ini dilakukan dengan metode bermain sambil belajar melalui dongeng tentang binatang yang memuat pelajaran tentang bagaimana mencintai diri sendiri, berani menerima kekurangan diri dengan fokus pada kelebihan yang dimiliki sehingga dapat membentuk karakter anak yang mandiri, mencintai diri 
sendiri, mudah bersosialisasi, berani mengemukakan pendapat dan toleransi kepada sesama.

1) Mendongeng Digital

Kegiatan mendongeng dapat dilakukan dengan menggunakan media gambar, boneka tangan atau boneka jari melalui media daring yang kemudian dikenal dengan istilah mendongeng digital. Mendongeng digital merupakan media yang tepat untuk digunakan pada masa pandemi Covid-19 ini dimana anak-anak atau peserta didik dapat mendengarkan cerita sekaligus belajar tanpa mengurangi interaksi diantara peserta didik maupun peserta didik dengan pendongeng. Mendongeng digital menurut Septiana (2018, p. 130) “...menggunakan media yang menarik dan disampaikan dengan cara yang berbeda dari pendekatan tradisional, topik yang dipilih disesuaikan dengan aspek dan tugas perkembangan anak." Menyajikan dongeng yang menarik tidak hanya dari segi cerita namun juga dari cara penyampaian cerita bisa dilakukan baik secara luring maupun daring dengan mempertimbangkan isi cerita dan muatan moral yang terdapat didalam cerita. Mendongeng digital merupakan media yang juga dapat menarik minat peserta didik untuk mendengarkan cerita sekaligus memanfaatkan teknologi yang ada tanpa mengurangi tujuan dan manfaat mendengarkan cerita. "Digital storytelling atau mendongeng digital, merujuk pada penggunaan media atau konten digital seperti teks, hypertext, gambar, audio maupun video dalam aktivitas bercerita dengan cara menggabungkan narasi pembuat cerita dengan multimedia" (Sukirman, 2016, p. 56).

Dongeng berbasis digital juga dapat digunakan untuk merangsang pertumbuhan dan perkembangan kecerdasan emosional anak dan juga mengembangkan karakter anak menjadi lebih peka terhadap lingkungan sekitar dan berinteraksi dengan lebih baik secara sosial dan emosional. Hal ini selaras dengan pendapat Sulistianingsih (2017, p.122) bahwa "pemilihan model dongeng berbasis digital dipilih untuk meningkatkan perkembangan kecerdasan emosional anak karena melalui metode dongeng inilah diharapkan mampu menularkan pengetahuan dan menanamkan nilai budi pekerti luhur secara efektif dan anak-anak menerima dengan senang hati." Pembelajaran pada anak usia sekolah dasar membutuhkan metode yang tepat dan menarik karena pada usia tersebut mereka masih muda sehingga unsur bermain juga merupakan hal yang penting dalam menyambpaikan isi pembelajaran. Media dan metode yang menarik dan menyenangkan akan membuat anak-anak atau peserta didik lebih antusias dan bersemangat dalam belajar. Selain menarik dan menyenangkan, perlu juga diperhatikan soft skill atau karakter anak yang turut dikembangkan sesuai usia mereka.

2) Soft skill Untuk Perkembangan Karakter Anak

Pendidikan anak usia Sekolah Dasar (SD) tidak hanya pada kemampuan teknis ( hard skill) namun juga pada kemampuan mengelola diri dan orang lain (soft skill). Dua kemampuan ini harus berjalan secara beriringan dan dinamis untuk menunjang tumbuh kembang anak baik dari segi kognitif, afektif, psikomotor dan perkembangan karakter. Keseimbangan antar hard skills dan soft skills dimaksudkan agar siswa kelak menjadi seorang yang sukses secara profesional dan dalam kehidupan sehari-hari. Sailah (2008) membagi soft skills menjadi dua bagian, yaitu intrapersonal skills dan interpersonal skills. Intrapersonal skills merupakan keterampilan individu dalam 
mengatur diri sendiri. Intrapersonal skills sebaiknya terlebih dahulu dibenahi sebelum seseorang individu mulai berinteraksi dengan individu lainnya. Adapun Interpersonal skills adalah keterampilan seseorang yang diperlukan dalam berhubungan dengan orang lain. Namun apa sebenarnya yang dimaksudkan dengan soft skill tentunya perlu dibahas terlebih dahulu. Menurut Elfindri dkk (2010, p. 67), soft skills didefinisikan sebagai berikut:

Soft skills merupakan keterampilan dan kecakapan hidup, baik untuk sendiri, berkelompok, atau bermasyarakat, serta dengan Sang Pencipta. Dengan mempunyai soft skills membuatkeberadaan seseorang akan semakin terasa di tengah masyarakat. Keterampilan akan berkomunikasi, keterampilan emosional, keterampilan berbahasa, keterampilan berkelompok,memiliki etika dan moral, santun dan keterampilan spiritual.

Keterampilan dan kecakapan dalam hidup baik secara mandiri maupun dalam bermasyarakat sebaiknya diperkenalkan sedini mungkin baik di tingkat Taman Kanak-Kanak maupun Sekolah Dasar. Kemampuan dalam berinteraksi dengan kelompok atau masyarakat dapat menunjang keterampilan dan kemampuan teknis yang diperoleh secara formal maupun non-formal. Jika kemampuan teknis tidak ditunjang dengan kemampuan mengelola diri sendiri dan orang lain maka akan terjadi ketimpangan dalam tumbuh kembang anak terutama dalam hal perkembangan karakternya. Pembentukan karakter sangat penting untuk dimulai sejak dini baik saat masih di Taman Kanak-Kanak dan berlanjut ke tingkat Sekolah Dasar. Pembentukan karakter anak usia dini dapat mengikuti suatu pola tertentu, yaitu suatu perilaku yang teratur, disiplin, dan baku (sesuai standar) (Nashikhah, 2016, p. 35).

Pengertian soft skill mencakup keterampilan sadar diri (self awareness), percaya diri (self confidence), menangani kelemahan diri (effort to handle self-weakness), bertanggungjawab terhadap diri sendiri (responsibilities), membuka diri (openness), tegas (assertiveness), berani mengambil keputusan sendiri, menangani stres (self effort to handle stressful) dan berani menyampaikan pendapat dan perasaannya (courage to express opinion and personal feelings). Secara umum soft skills diartikan sebagai kemampuan di luar kemampuan teknis dan akademis, yang lebih mengutamakan kemampuan intra dan interpersonal" (Prastiwi, 2011, p. 3, dikutip dalam Rusmardiana, 2016, p. 99). Sedangkan menurut Suyanto (2010, p. 35, dikutip dalam Rosmi, 2016, p.55), terdapat sembilan pilar karakter yang berasal dari nilainilai luhur universal, yaitu: 1) karakter cinta Tuhan dan segenap ciptaan-Nya; 2) kemandirian dan tanggung jawab; 3) kejujuran/amanah, diplomatis; 4) hormat dan santun; 5) dermawan, suka tolong-menolong dan gotong royong/ kerjasama; 6) percaya diri dan pekerja keras; 7) kepemimpinan dan keadilan; 8) baik dan rendah hati, 9) karakter toleransi, kedamaian, dan kesatuan. Dalam kegiatan mendongeng digital bagi anak-anak Sanggar Baca Jendela Dunia, soft skill ataupun karakter yang ingin dikembangkan adalah cinta Tuhan dan segenap ciptaannya, percaya diri, toleransi, hormat dan santun, baik dan rendah hati dan kemandirian dan tanggung jawab melalui cerita yang disajikan oleh pendongeng.

Kegiatan mendongeng secara digital tidak hanya meningkatkan kemampuan kognitif atau kemampuan teknis anak-anak usia Sekolah Dasar, namun juga menumbuhkan 
dan mengembangkan kemampuan mengelola diri sendiri dan orang lain atau dikenal dengan istilah soft skill. Berkaitan dengan hal tersebut maka pihak dosen dan mahasiswa Program Studi Sastra Inggris Universitas Pamulang bekerjasama dengan pihak Sanggar Baca Jendela Dunia mengadakan kegiatan "Mendongeng Digital Sebagai Media Peningkatan Soft skill Santri Sanggar Baca Jendela Dunia". Melalui kegiatan ini para santri diajak belajar dan bermain sekaligus mengembangkan karakter cinta Tuhan dan segenap ciptaannya, percaya diri, toleransi, hormat dan santun, baik dan rendah hati dan kemandirian dan tanggung jawab.

\section{B. Pelaksanaan dan Metode}

Mendongeng Virtual dilaksanakan melalui media zoom pada hari Jumat, 2 April 2021 dihadiri oleh 30 santri Sanggar Baca Jendela Dunia, Legoso - Tangerang selatan, Banten. Para santri atau Peserta tersebut berlatar belakang Pendidikan Pra Sekolah dan kelas 1 sampai dengan kelas 6 Sekolah Dasar yang merupakan santri Taman Pendidikan Agama dalam naungan Sanggar Baca Jendela Dunia. Dengan kata lain, para peserta yang menjadi sasaran kegiatan $\mathrm{PkM}$ adalah anak-anak dengan rentang umur 4-12 tahun yang terdiri dari 14 santri dan 16 santriwati. Mereka sedang menggemari menggunakan handphone, terutama dalam masa pandemik Covid 19 dalam setahun ini, karena kegiatan belajar mengajar dan mengaji dialihkan dengan menggunakan dawai digital, seperti telfon gengam dan laptop. Dengan demikian, para santri tersebut sedang belajar memulai, melaksanakan dan memahami digital literasi.

Kegiatan PkM ini merupakan aktifitas untuk meningkatkan kemampuan literasi digital para santri dan santriwati dan memberikan kesadaran untuk menggunakan dawai mereka untuk kegiatan yang edukatif terkait dengan soft skills mereka. Selain itu, kegiatan mendongeng virtual juga dilaksanakan dengan memberikan alternatif aktifitas yang dapat mengarahkan mereka pada keadaan yang menyenangkan memperoleh Pendidikan karakter, penambahan kosa kata sederhana dalam Bahasa Inggris, dan bermain sambil belajar untuk memperluas keterampilan digital literasi mereka.

Untuk mendorong dan meningkatkan keterampilan penguasaan literasi digital di luar kegiatan belajar formal, para santri di berikan kegiatan edukatif melalui dongeng virtual yang dikembangkan melalui diskusi, bermain, dan bernyanyi yang dilakukan melalui dawai digital. Demikian pula untuk asesmen dilakukan dengan menggunakan aplikasi yang menuntun para santri memperoleh pengetahuan dan keterampilan terkait dengan digital literasi.

\section{Hasil dan Pembahasan}

Dongeng virtual dilaksanakan sebagai kegiatan peningkatan kemampuan literasi digital para santri. Selain media mendongeng dilakukan dengan dalam jaringan melalui zoom, materi dongeng divirtualkan dengan membuat picture book cetak berjudul The Royal Raven, karya Hans Wilhelm, menjadi Power Points, sehingga memudahkan tim PkM dalam menyajikan dongeng tersebut. The Royal Raven mengisahkan seekor Gagak yang tidak menyukai penampilan aslinya yang hitam dan 
menginginkan merubah penampilannya untuk menjadi lebih menarik seperti burungburung lainnya. Untuk memenuhi keinginannya, Gagak meminta ahli sihir untuk mengubah dirinya menjadi burung terindah. Dengan penampilannya yang terindah tersebut, Gagak memantaskan dirinya untuk berada di istana daripada di hutan. Di tempat yang baru ini Gagak semula merasa bangga dan tinggi hati, yang akhirnya dikurung dalam sangkar. Gagak kehilangan kebebasan dirinya dan akhirnya melepaskan semua bulu-bulu indahnya dan kembali menjadi dirinya sendiri dan berkumpul dengan gagak-gagak lainnya. Namun dongeng disampaikan secara verbal sesuai dengan gambar pada buku cerita tersebut.

Dipilihnya judul tersebut untuk dongeng virtual, karena tema yang direpresentasikan dalam buku tersebut mengandung nilai-nilai untuk mensyukuri dengan apa yang sudah dimiliki, menghargai perbedaan, dan menerima kebersamaan. Dongeng tersebut juga memberikan pemahaman untuk tidak sombong dan serakah. Pemahaman akan nilai-nilai tersebut ditunjukkan oleh para santri melalui jawaban mereka dalam menjawab pertanyaan-pertanyaan dalam diskusi setelah dongeng selesai diceritakan.
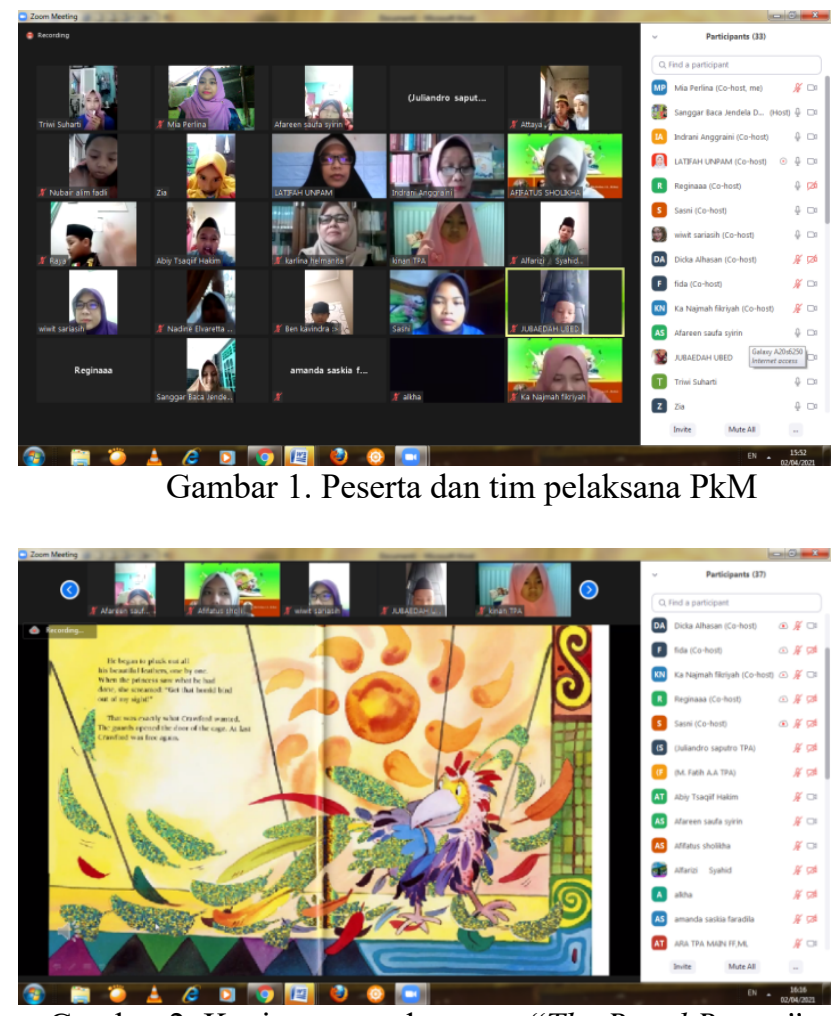

Gambar 2. Kegiatan mendongeng "The Royal Raven"

Tanggapan para santri terhadap nilai-nilai tersebut menunjukkan bahwa para santri dengan latar belakang pendidikan Sekolah Dasar aktif menjawab diskusi dongeng The Royal Raven. Pertanyaan-pertanyaan diskusi yang menggali pemahaman tentang nilai-nilai tersebut diantaranya adalah:

a. Apa yang terjadi pada si Gagak?

b. Bagaimana Gagak mencoba mengubah dirinya setiap hari?

c. Mengapa Gagak ingin mengubah penampilannya setiap hari? 
d. Bagaimana sikap Gagak setelah penampilannya berubah?

e. Apakah Gagak Bahagia dengan penampilan barunya? Mengapa?

f. Bagaimanakah perilaku Gagak?

Sedangkan para santri dengan latar belakang pra sekolah menyimak jawaban para santri yang lebih senior. Dalam hal ini terjadi saling belajar antar santri pra sekolah dan Sekolah Dasar. Proses saling belajar tersebut juga dilakukan bersama ibu/wali santri yang mendampingi para santri pra-sekolah selain para pendamping sanggar Baca Jendela Dunia. Dengan kata lain, kegiatan dongeng virtual tersebut melibatkan para santri pra sekolah, Sekolah Dasar, orangtua, pendamping sanggar dan tim pelaksana PkM Program Studi Sastra Inggris Universitas Pamulang.

Dalam kegiatan penguatan dan pengembangan dongeng The Royal Raven, para santri memperoleh pengenalan kosakata Bahasa Inggris dasar dengan kelompok kosakata yang mencakup tiga kategori yaitu jenis burung, warna terkait dengan warna burung, dan nama-nama hari. Kegiatan ini dilaksanakan dengan mengenalkan 10 jenis burung yang ada dalam The Royal Raven yang ditampilkan melalui Power point dengan gambar animasi dan foto kesepuluh jenis burung tersebut yang diawali dengan nama burung yang terdiri satu suku kata, kemudian dilanjutkan dengan dua suku kata, dan terakhir tiga suku kata dan lebih yaitu Owl, Dove, Swan, Raven, Parrot, Canary, Peacock, Flamingo, Humming Bird, dan Paradise Birds. Dengan peningkatan jumlah suku kata dari kosakata jenis burung yang diberikan tersebut, para santri dimudahkan dalam pengucapan dan penguasaan kosakata tersebut, terutama untuk para santri prasekolah. Pengulangan dengan system parroting menstimulasi kemampuan menyimak gambar, berpikir asosiatif, dan memperoleh kosakata jenis burung beserta warna yang ditampilkan oleh warna jenis burung tersebut. Demikian juga untuk pengenalan namanama hari dalam Bahasa Inggris; Monday, Tuesday, Wednesday, Thursday, Friday, Saturday, and Sunday dikenalkan melalui parroting dan terjemahan, serta bernyanyi bersama para santri. Kegiatan ini tidak saja menambah kosakata nama-nama hari dalam Bahasa Inggris, tetapi juga kemampuan komunikasi, dan seni para santri.

Asesmen dengan aplikasi Whiteboard.fi menunjukkan antusias para santri dalam merespon mengasosiasikan perasaan para santri dalam mengikuti kegiatan mendongeng virtual melalui memasangkan/matching simbol berbagai emoji ekspresi perasaan mereka mengikuti kegiatan dongeng virtual, diikuti dengan kegiatan menunjukkan gambar animasi 10 jenis burung yang tersedia dalam aplikasi tersebut saat nama jenis burung disebutkan, serta menuliskan nama burung tersebut bagi mereka yang dapat menuliskan nama jenis burung. Para santri diberikan asesmen sesuai dengan tingkat kemampuan mereka. Para santri pra-sekolah mengerjakan asesmen yang mengasosiasikan perasaan mereka dalam mengikuti kegiatan, serta jenis burung yang telah dibahas. Dengan kata lain, asesmen yang diberikan melalui aplikasi Whiteboard. $f i$ menunjukkan kegembiraan para santri dalam mengikuti kegiatan dengan pilihan emoji kegembiraan yang dipilih, penguasaan jenis burung, dan berpikir virtual/virtual thinking. Kemampuan literasi para santri ditunjukkan dengan pengunaan zoom sebagai media pelaksanaan kegiatan, presentasi dongeng dan materi penguatan dan pengembangannya tentang dongeng dilakukan dengan materi 
virtual seperti Power Point, serta asesmen dengan aplikasi Whiteboard.fi yang memungkinkan para santri untuk bereksperimen.

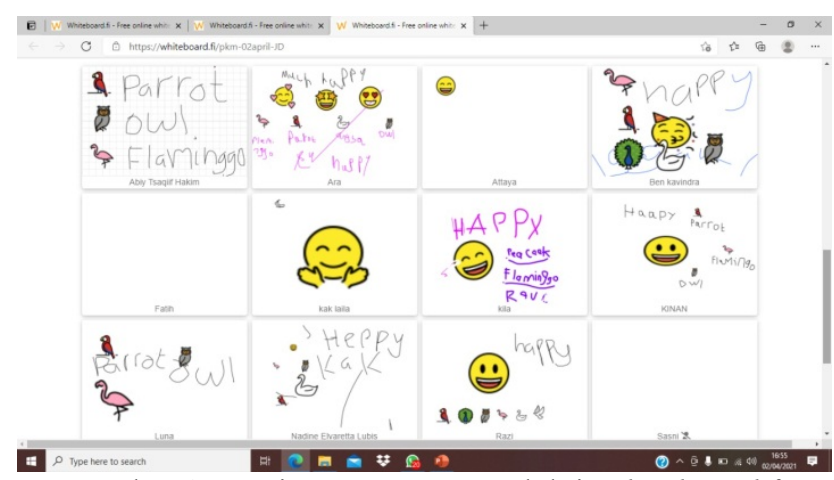

Gambar 3. Kegiatan asesmen melalui Whiteboard.fi

\section{Penutup}

\section{Simpulan}

Kegiatan Pengabdian kepada Masyarakat yang bertema mendongeng digital sebagai media peningkatan soft skill santri Sanggar Baca Jendela Dunia (SBJD) dilakukan secara daring dengan menggunakan aplikasi zoom karena dilaksanakan dalam masa pandemik Covid-19. Kegiatan yang dilakukan adalah mendongeng dengan menampilkan slide power point, lalu menyebutkan karakter-karakter yang dapat dicontoh dan dihindari dari dongeng yang sudah disampaikan. Kemudian sebagai kegiatan asesmen, peserta didik/santri diajak untuk menggunakan aplikasi whiteboard.fi secara daring melalui tautan yang dibagikan oleh tim/anggota PkM. Dari hasil kegiatan PkM, dapat disimpulkan bahwa rentang usia para santri yang bervariasi, yakni antara 4-12 tahun, menjadi kelemahan sekaligus kekuatan pelaksanaan kegiatan $\mathrm{PkM}$. Sebagai contoh, adanya kesenjangan penguasaan pemakaian alat digital secara mandiri, dimana santri pra sekolah bergantung pada orangtua/wali santri yang mendampingi. Di sisi lain, kegiatan PkM yang dilakukan memberi kontribusi berupa peningkatan motivasi bagi santri pra sekolah untuk belajar terkait penguasaan digital literasi sejak usia dini. Sementara itu, bagi santri tingkat Sekolah Dasar, kegiatan dongeng digital dapat meningkatkan kemampuan literasi digital mereka sekaligus model dan motivator bagi santri pra sekolah. Dengan demikian, terjadi proses saling belajar antara santri pra sekolah dan tingkat Sekolah Dasar.

\section{Saran}

Untuk kegiatan PkM selanjutnya, diharapkan melakukan kegiatan dengan teknik yang serupa namun menggunakan media pembelajaran yang lebih bervariasi. Hal ini baik untuk dilakukan agar dapat diketahui efektifitas dari kegiatan mendongeng terhadap peserta didik. 


\section{Ucapan Terima Kasih}

Ucapan terima kasih kami sampaikan kepada LPPM Universitas Pamulang yang memberikan dana pelaksanaan PkM dan jajaran Kaprodi Sastra Inggris atas dukungan dan bimbingannya sehingga kegiatan Pengabdian kepada Masyarakat ini dapat berjalan dengan baik. Serta kami ucapkan pula ucapan terima kasih kepada pihak mitra Sanggar Baca Jendela Dunia yang telah memberikan kesempatan kepada tim PkM Prodi Sastra Inggris Universitas Pamulang untuk ikut serta dalam berkontribusi pada masyarakat di Legoso Ciputat Timur.

\section{DAFTAR PUSTAKA}

Elfindri, E., Wello, M.B., Tobing, P., Yanti, F., Zein, E. E., \& Indra, R. (2010). Soft skill untuk pendidik. Baduose Media

Nashikhah, M. (2016). Peranan soft skill dalam menumbuhkan karakter anak TPA. Tadris: Jurnal Keguruan dan ilmu Tarbiyah 1(1), 33-39. https://ejournal.radenintan.ac.id/index.php/tadris

Rosmi, Y.F. (2016). Pendidikan jasmani dan pengembangan karakter siswa sekolah dasar. Wahana 66(1), 55-61. https://doi.org/10.36456/wahana.v66i1.482

Rusmardiana, A. (2016). Soft skills terhadap karakter siswa sekolah sasar. Faktor:Jurnal Ilmiah Kependidikan 3(2), 97-104. http://dx.doi.org/10.30998/fjik.v3i2.775

Sailah, I. (2008). Pengembangan soft skills di perguruan tinggi. http://sailah.50webs.com.html

Septiana, N. Z. (2018). Digital storytelling untuk mengembangkan aspek spiritual anak Taman Kanak-Kanak (TK) Al-Hidayah Bakung 01 kabupaten Blitar. Realita 16(2), 129-140. https://doi.org/10.30762/realita.v16i2.1035

Sukirman, S. (2016). Digital storytelling interaktif dan menggembirakan menggunakan augmented reality. Prosiding Seminar Nasional Elinvo (Tema: Transformation of Electronics and Information in Daily Life: Challenges and Opportunities for Asean Economic Community) (pp.55-60).

Sulistianingsih, E. (2017). Efektifitas model pembelajaran berbasis dongeng digital untuk meningkatkan kecerdasan emosi peserta didik. Jurnal Penelitian Pendidikan $34(2)$,

121-126. https://journal.unnes.ac.id/nju/index.php/JPP/article/view/7252

Wilhelm, H. (2000). The royal raven. Random House. 